\title{
Forecasting the Demand of Clinical Pharmacist Workforce in Future Fifteen Years (2016-2030) at all Healthcare institutions in Saudi Arabia
}

\author{
Yousef Ahmed Alomi i", Saeed Jamaan Alghamdi², Radi Abdullah Alattyh ${ }^{2}$ \\ ${ }^{I}$ The Past General Manager of General Administration of Pharmaceutical Care and The Past Head, National Clinical pharmacy, \\ and pharmacy practice and Pharmacy $R$ and D Administration, Ministry of Health, Riyadh, KSA. \\ ${ }^{2}$ General Administration of Pharmaceutical Care, Ministry of Health, P.O.BOX 100, Riyadh 11392, Riyadh, KSA.
}

Received: 13 December 2017;

Accepted: 28 February 2018

*Correspondence to:

Dr. Yousef Ahmed Alomi,

The Past General Manager of General Administration of Pharmaceutical Care The Past Head, National Clinical pharmacy, and pharmacy practice

Head, Pharmacy R and D Administration Ministry of Health, P.O.BOX 100, Riyadh 11392 , Riyadh, Saudi Arabia. Email:yalomi@gmail.com

Copyright: (c) the author(s),publisher and licensee Indian Academy of Pharmacists. This is an open-access article distributed under the terms of the Creative Commons Attribution Non-Commercial License, which permits unrestricted non-commercial use, distribution, and reproduction in any medium, provided the original work is properly cited.

\begin{abstract}
Objectives: The workforce of clinical pharmacist is one the elements of pharmacy strategic plan in Saudi Arabia. The purpose of this study is to explore the demand for clinical pharmacist's workforce in fifteen years (2016-2030) at Ministry of Health hospitals and primary care centers, and all Non-Ministry of Health hospitals in Saudi Arabia. Methods: It is a prospective analysis of fifteen years (2016-2030) of health care provider hospital and $\mathrm{MOH}$ primary care centers projecting demand of clinical pharmacists in the future. All data were derived from Ministry of health statistical Year Books. It included current and future demand for clinical pharmacist workforces at hospitals in Kingdom of Saudi Arabia. The type of hospital included having bed capacity of 50-1500 beds with Adults public hospitals, pediatrics and maternity hospitals, Psychiatric hospitals, Diabetic centers, Cardiology centers, Oncology Centers, Renal Dialysis Centers, and Medical cities. All calculations were based on $\mathrm{MOH}$ clinical pharmacist workforce standards of hospitals. The calculations were per each region for a total of twenty-one regions for $\mathrm{MOH}$ hospital and primary care centers, the expected number of clinical pharmacist requirement in the coming years 2016-2030 were estimated per each sector across Saudi Arabia. Result: The total numbers of hospitals were 466 in the kingdom of Saudi Arabia, 274 (58.8\%) Ministry of Health hospitals, 152 (32.6\%) private hospitals, and $40(8.6 \%)$ non-MOH governmental hospitals. Over the eleven years, the average number of hospitals were (423.45) with a range number of (384-467), and the total number was (467). The total average demand of clinical pharmacists at $\mathrm{MOH}$ hospitals by the year 2030 will be $(6,018.96)$ with range $(5,020.20-7,132.26)$ while the average total demand of clinical pharmacists at $\mathrm{MOH}$ primary care centers by the year 2030 will be (2787.55) with range $(2,325.00-3,303.16)$. The total requirement of a clinical pharmacist in all sectors by the year 2030 will be $(12,077.88)$ with range $(8,501.28-12,077.88)$. Conclusion: The MOH hospitals and primary care centers sectors will be with the highest demand for clinical pharmacists in the future. Targeting for more graduated clinical pharmacist from the college of pharmacies, opening new clinical pharmacist jobs, and implementation of new vision of pharmacy practice by 2030 is required in Saudi Arabia. Key word: Clinical pharmacist, Workforces, Ministry of health, Saudi arabia.
\end{abstract}

\section{INTRODUCTION}

The Ministry of Health started with the logo "the patient first" for achievement of several elements during the updated healthcare system strategic plan. ${ }^{[1]}$ That is required to improve healthcare Human Resources including pharmacy practice. Clinical pharmacy staff was new workforce at $\mathrm{MOH}$ standard, released through the general administration of pharmaceutical services during first pharmacy strategic plan and updated with a new one. ${ }^{[2]}$ Despite the clinical pharmacy was started at the non$\mathrm{MOH}$ organization in mid-1985 and expanded in the mid-1990s but still the calculation of clinical pharmacist demand and requirements for pharmacy future services was not done ${ }^{[3]}$ Several studies reported pharmacist workforces including the clinical pharmacy workforce Especially in United States of America (USA) and other countries. ${ }^{[4-15]}$ Few studies reported the projection of clinical pharmacist in the future. ${ }^{[6,16]} \mathrm{It}$ is hard to find an invigoration in Saudi Arabia, or Gulf and Middle East countries about clinical pharmacy workforce demand currently and in the future. The objective of this study is to explore the current and future clinical pharmacist demand at all healthcare sectors in Kingdom of Saudi Arabia.

\section{METHODS}

It is a prospective analysis of fifteen years (2016-2030) of health care provider hospital and $\mathrm{MOH}$ primary care centers projecting demand of clinical pharmacists in the future. All data were derived from Ministry of health statistical Year Books. ${ }^{[17-27]}$ It included the current and future demand for clinical pharmacist's workforces at hospitals in Kingdom of Saudi Arabia. The type of hospital included having bed capacity of 50-1500 beds with Adults public hospitals, pediatrics and maternity hospitals, Psychiatric hospitals, Diabetic centers, Cardiology centers, Oncology Centers, Renal Dialysis Centers, and Medical cities. All clinical Pharmacist works at $\mathrm{MOH}$ Hospitals or Primary care centers and non-MOH government hospitals including; University Hospitals, Armed Forces Hospitals, National Gaud Hospitals, Security Forces hospitals, King Faisal Specialist hospital and research center, Royal Commission for Jubail and Yanbu Hospitals, Aramco Hospitals, included in the study. All private hospitals also included in the study. All community pharmacies or pharmacy technician excluded from the study. All clinical pharmacists were expected to provide pharmaceutical according to ASHP definition and requirements. All type of pharmacy services were based on Saudi Central Board of hospital accreditation, a joint 


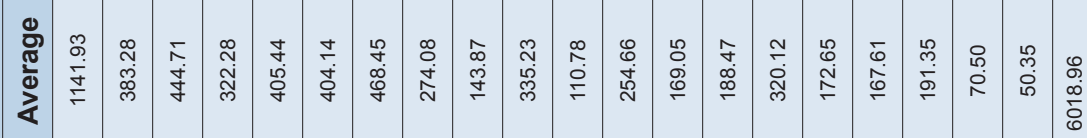

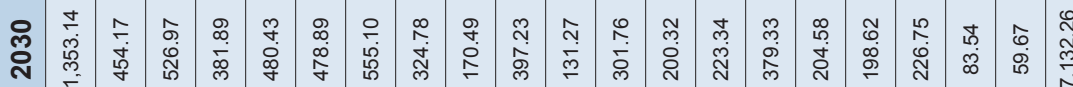

ล

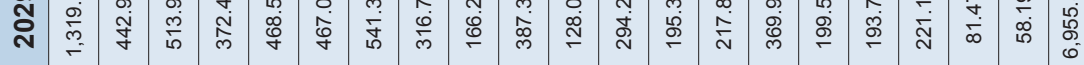

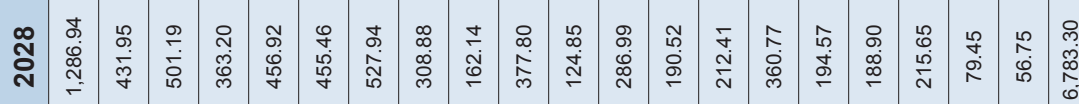

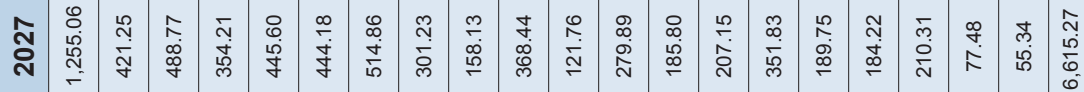

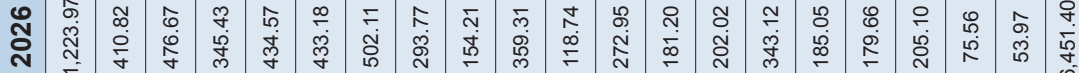

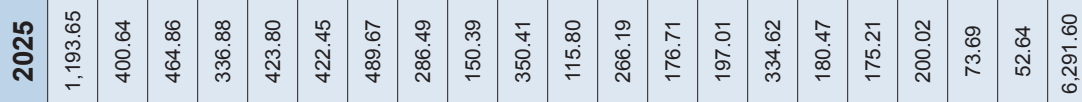

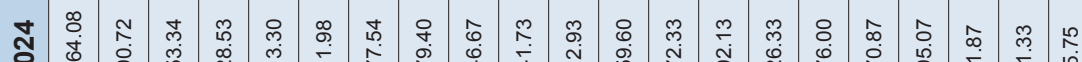

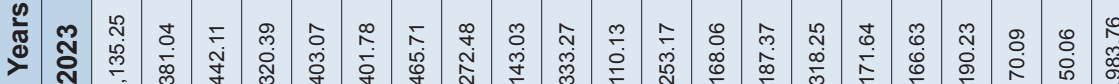

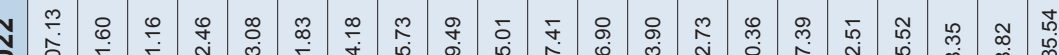

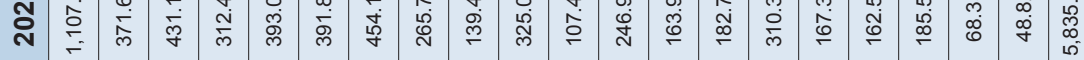

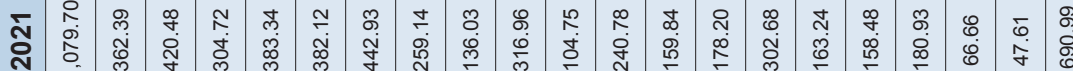

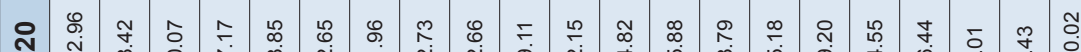

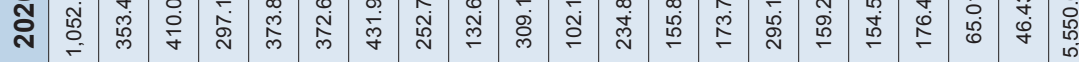

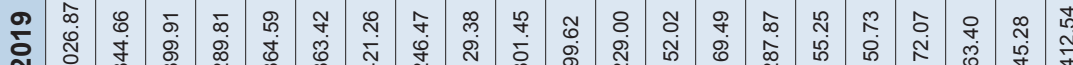

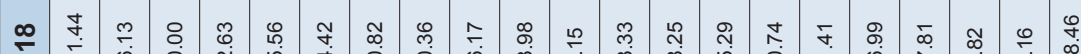

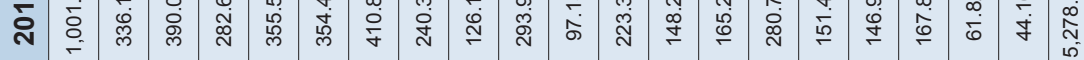

Tస

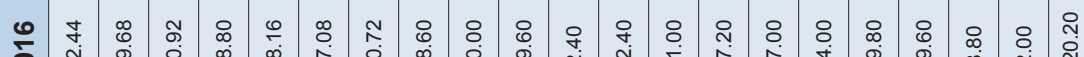

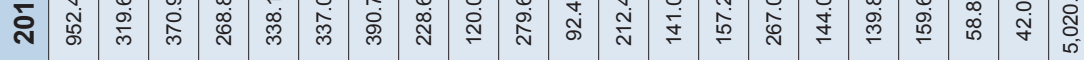

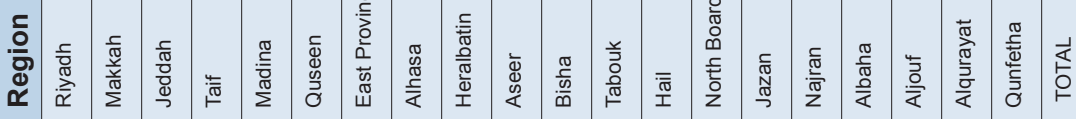

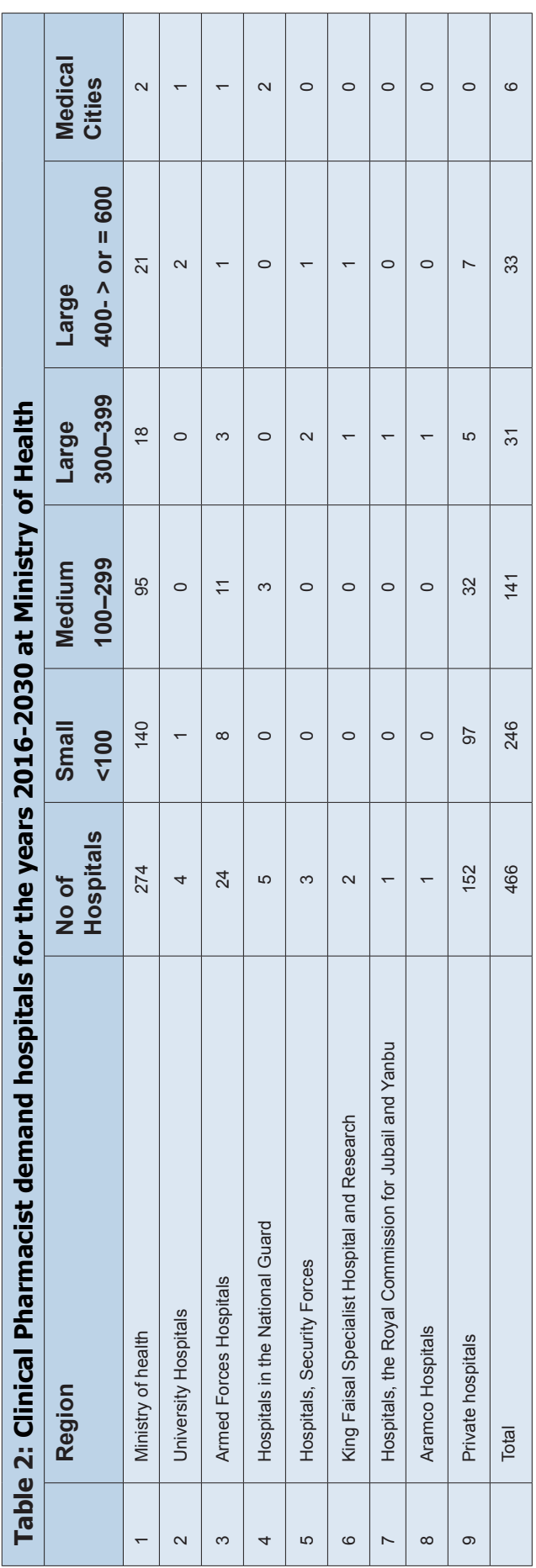


Table 3: Primary care center (PCC) clinical Pharmacist demand for the years 2016-2030 at Ministry of Health.

\begin{tabular}{|c|c|c|c|c|c|c|c|c|c|c|c|c|c|c|c|c|}
\hline \multirow[b]{2}{*}{ Region } & \multicolumn{15}{|c|}{ Years } & \multirow[b]{2}{*}{ Average } \\
\hline & 2016 & 2017 & 2018 & 2019 & 2020 & 2021 & 2022 & 2023 & 2024 & 2025 & 2026 & 2027 & 2028 & 2029 & 2030 & \\
\hline Riyadh & 424.00 & 434.77 & 445.81 & 457.14 & 468.75 & 480.65 & 492.86 & 505.38 & 518.22 & 531.38 & 544.88 & 558.72 & 572.91 & 587.46 & 602.38 & 508.35 \\
\hline Makkah & 83.00 & 85.11 & 87.27 & 89.49 & 91.76 & 94.09 & 96.48 & 98.93 & 101.44 & 104.02 & 106.66 & 109.37 & 112.15 & 115.00 & 117.92 & 99.51 \\
\hline Jeddah & 90.00 & 92.29 & 94.63 & 97.03 & 99.50 & 102.03 & 104.62 & 107.27 & 110.00 & 112.79 & 115.66 & 118.60 & 121.61 & 124.70 & 127.86 & 107.91 \\
\hline Taif & 121.00 & 124.07 & 127.22 & 130.46 & 133.77 & 137.17 & 140.65 & 144.22 & 147.89 & 151.64 & 155.50 & 159.45 & 163.50 & 167.65 & 171.91 & 145.07 \\
\hline Madina & 162.00 & 166.11 & 170.33 & 174.66 & 179.10 & 183.65 & 188.31 & 193.09 & 198.00 & 203.03 & 208.18 & 213.47 & 218.89 & 224.45 & 230.16 & 194.23 \\
\hline Quseen & 177.00 & 181.50 & 186.11 & 190.83 & 195.68 & 200.65 & 205.75 & 210.97 & 216.33 & 221.83 & 227.46 & 233.24 & 239.16 & 245.24 & 251.47 & 212.21 \\
\hline $\begin{array}{l}\text { East } \\
\text { Province }\end{array}$ & 140.00 & 143.56 & 147.20 & 150.94 & 154.78 & 158.71 & 162.74 & 166.87 & 171.11 & 175.46 & 179.91 & 184.48 & 189.17 & 193.97 & 198.90 & 167.85 \\
\hline Alhasa & 70.00 & 71.78 & 73.60 & 75.47 & 77.39 & 79.35 & 81.37 & 83.44 & 85.55 & 87.73 & 89.96 & 92.24 & 94.58 & 96.99 & 99.45 & 83.93 \\
\hline Heralbatin & 40.00 & 41.02 & 42.06 & 43.13 & 44.22 & 45.34 & 46.50 & 47.68 & 48.89 & 50.13 & 51.40 & 52.71 & 54.05 & 55.42 & 56.83 & 47.96 \\
\hline Aseer & 249.00 & 255.32 & 261.81 & 268.46 & 275.28 & 282.27 & 289.44 & 296.79 & 304.33 & 312.06 & 319.99 & 328.11 & 336.45 & 344.99 & 353.76 & 298.54 \\
\hline Bisha & 85.00 & 87.16 & 89.37 & 91.64 & 93.97 & 96.36 & 98.80 & 101.31 & 103.89 & 106.53 & 109.23 & 112.01 & 114.85 & 117.77 & 120.76 & 101.91 \\
\hline Tabouk & 83.00 & 85.11 & 87.27 & 89.49 & 91.76 & 94.09 & 96.48 & 98.93 & 101.44 & 104.02 & 106.66 & 109.37 & 112.15 & 115.00 & 117.92 & 99.51 \\
\hline Hail & 105.00 & 107.67 & 110.40 & 113.21 & 116.08 & 119.03 & 122.05 & 125.15 & 128.33 & 131.59 & 134.93 & 138.36 & 141.88 & 145.48 & 149.17 & 125.89 \\
\hline $\begin{array}{l}\text { North } \\
\text { Boarder }\end{array}$ & 47.00 & 48.19 & 49.42 & 50.67 & 51.96 & 53.28 & 54.63 & 56.02 & 57.44 & 58.90 & 60.40 & 61.93 & 63.51 & 65.12 & 66.77 & 56.35 \\
\hline Jazan & 178.00 & 182.52 & 187.16 & 191.91 & 196.79 & 201.78 & 206.91 & 212.16 & 217.55 & 223.08 & 228.75 & 234.56 & 240.51 & 246.62 & 252.89 & 213.41 \\
\hline Najran & 68.00 & 69.73 & 71.50 & 73.31 & 75.18 & 77.09 & 79.04 & 81.05 & 83.11 & 85.22 & 87.39 & 89.61 & 91.88 & 94.22 & 96.61 & 81.53 \\
\hline Albaha & 105.00 & 107.67 & 110.40 & 113.21 & 116.08 & 119.03 & 122.05 & 125.15 & 128.33 & 131.59 & 134.93 & 138.36 & 141.88 & 145.48 & 149.17 & 125.89 \\
\hline Aljouf & 42.00 & 43.07 & 44.16 & 45.28 & 46.43 & 47.61 & 48.82 & 50.06 & 51.33 & 52.64 & 53.97 & 55.34 & 56.75 & 58.19 & 59.67 & 50.35 \\
\hline Alqurayat & 19.00 & 19.48 & 19.98 & 20.48 & 21.01 & 21.54 & 22.09 & 22.65 & 23.22 & 23.81 & 24.42 & 25.04 & 25.67 & 26.32 & 26.99 & 22.78 \\
\hline Qunfetha & 37.00 & 37.94 & 38.90 & 39.89 & 40.90 & 41.94 & 43.01 & 44.10 & 45.22 & 46.37 & 47.55 & 48.76 & 49.99 & 51.26 & 52.57 & 44.36 \\
\hline TOTAL & $2,325.00$ & $2,384.06$ & $2,444.61$ & $2,506.70$ & $2,570.37$ & $2,635.66$ & $2,702.61$ & $2,771.25$ & $2,841.64$ & $2,913.82$ & $2,987.83$ & $3,063.72$ & $3,141.54$ & $3,221.34$ & $3,303.16$ & 2787.55 \\
\hline
\end{tabular}

commission of hospital accreditation, ASHP best practice standards, and general administration of the pharmaceutical care strategic plan..$^{[2,28-31]}$ All calculations were based on $\mathrm{MOH}$ clinical pharmacist workforce standards of hospitals. The calculations were per each region for a total of twenty-one regions for $\mathrm{MOH}$ hospital and primary care centers, the expected number of clinical pharmacist requirement in the coming years 2016-2030 per each sector were estimated across Saudi Arabia. All calculation done used Microsoft Excel version ten.

\section{RESULTS}

The total numbers of hospitals were 466 in the kingdom of Saudi Arabia, $274(58.8 \%)$ Ministry of Health hospitals, $152(32.6 \%)$ private hospitals, and $40(8.6 \%)$ non-MOH governmental hospitals. Over the eleven years, the average number of hospitals were (423.45) with a range number of (384-467), and the total number was (467) as explored in Table 1. The total average demand of clinical pharmacists at $\mathrm{MOH}$ hospitals by the year 2030 will be $(6,018.96)$ with range $(5,020.20-7,132.26)$ while the average total numbers demand of clinical pharmacists at $\mathrm{MOH}$ primary care centers by the year 2030 will be (2787.55) with range $(2,325.00-3,303.16)$ as explored in Table 2 and Table 3 . The high average requirement of the clinical pharmacists will be in Ministry of health regions $(6,018.96)$, followed by Private hospitals sector (2,507.43) and Armed Forces Hospitals (686.57) pharmacists. The total requirement of a clinical pharmacists in all sectors by the year 2030 will be $(12,077.88)$ with range $(8,501.28-12,077.88)$ as explored in Table 4.

\section{DISCUSSION}

The general administration of pharmaceutical care started pharmacy strategic plan in the mid-2000s and updated plan released in early 2010. ${ }^{[2]}$ The plan consisted of development all pharmacy practice services and clinical pharmacy programs. The pharmacy administration established more than thirty clinical pharmacy programs including but not limited to the national drug information services, national medication safety program, national pharmacy anticoagulant program and pharmacy pain management services. ${ }^{[3,32-35]}$ All clinical pharmacy services required a workforce with high qualifications and appropriate numbers. The pharmacy administration started new guidelines for the workforce at hospitals and primary care centers. ${ }^{[36,37]}$ However, the calculation of demand of clinical pharmacist workforce not yet founded at Ministry of Health organization or non-MOH institutions or private hospital; the authors investigated the clinical pharmacy services workforce demand at $\mathrm{MOH}$ hospital and primary healthcare centers with twenty different regions, and at all sectors including non-MOH governmental organization and the private sector. The finding showed of hospitals at all healthcare sectors was lower than what reported in old others. ${ }^{[6,16]}$ It was due to both studies were done in the USA with the highly significant difference in the population of our countries and USA. Also, the clinical pharmacist requirement in USA was $40 \%$ that is more than $\mathrm{MOH}$ clinical pharmacist standard. The most jobs of the clinical pharmacist should be available from Ministry of Health and private hospital, and that is because of the high number of hospitals. The results of demand primary care clinical pharmacist are confusing to compare with earlier studies because no such studies are available, and maybe this is the first study to discuss the demand clinical 


\begin{tabular}{|c|c|c|c|c|c|c|c|c|c|c|c|c|c|}
\hline & & 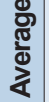 & $\begin{array}{l}0 \\
0 \\
\infty \\
\infty \\
0 \\
0 \\
0\end{array}$ & $\mid \begin{array}{c}\tilde{N} \\
\stackrel{\infty}{\sim} \\
\stackrel{N}{N}\end{array}$ & $\begin{array}{l}\hat{f} \\
\stackrel{0}{0} \\
0 \\
0\end{array}$ & $\begin{array}{l}\stackrel{0}{m} \\
\stackrel{m}{m}\end{array}$ & $\begin{array}{l}\bar{m} \\
\stackrel{d}{\sim} \\
\end{array}$ & $\begin{array}{l}\hat{f} \\
\stackrel{\hat{\theta}}{\sigma}\end{array}$ & $\begin{array}{l}\tilde{N} \\
\text { రे }\end{array}$ & 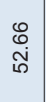 & 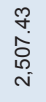 & $\begin{array}{l}0 \\
\stackrel{0}{\mathrm{j}} \\
\sigma \\
\stackrel{-}{0} \\
0\end{array}$ & $\begin{array}{l}\overline{5} \\
\stackrel{5}{\mathrm{j}} \\
\stackrel{\mathrm{m}}{\sigma}\end{array}$ \\
\hline & & 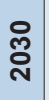 & 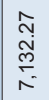 & 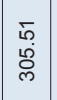 & 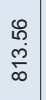 & 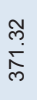 & 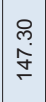 & 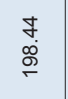 & 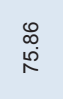 & ণ্ণ & 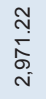 & $\begin{array}{l}\infty \\
\infty \\
\stackrel{N}{0} \\
\stackrel{0}{\sim} \\
\stackrel{n}{\sim}\end{array}$ & 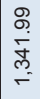 \\
\hline & & స્ণ & 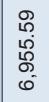 & $\begin{array}{l}\mathbf{S} \\
\stackrel{+}{N} \\
\stackrel{N}{*}\end{array}$ & 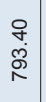 & $\begin{array}{l}\underset{N}{N} \\
\underset{ల}{\infty}\end{array}$ & 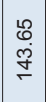 & 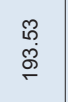 & ঙ. & $\begin{array}{l}\infty \\
\infty \\
0 \\
0\end{array}$ & 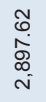 & $\begin{array}{l}R \\
\infty \\
\infty \\
\stackrel{1}{r} \\
F\end{array}$ & 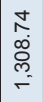 \\
\hline & & : & 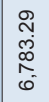 & $\mid \begin{array}{l}0 \\
0 \\
0 \\
\stackrel{D}{2}\end{array}$ & 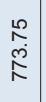 & 邑 & $\begin{array}{l}8 \\
\stackrel{8}{0} \\
\dot{9} \\
\leftarrow\end{array}$ & 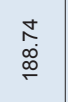 & $\stackrel{0}{\stackrel{N}{N}}$ & 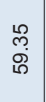 & 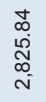 & $\begin{array}{l}\infty \\
\stackrel{\infty}{0} \\
\infty \\
\stackrel{\infty}{0} \\
\stackrel{-}{=}\end{array}$ & 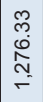 \\
\hline & & స్ิ & \begin{tabular}{|l}
$\tilde{N}$ \\
$\mathfrak{L}$ \\
$\tilde{0}$ \\
0 \\
0
\end{tabular} & $\begin{array}{l}0 \\
0 \\
\infty \\
\infty \\
N\end{array}$ & 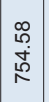 & 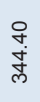 & 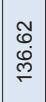 & $\begin{array}{l}8 \\
\dot{\infty} \\
\stackrel{+}{\leftarrow}\end{array}$ & 色 & $\begin{array}{l}\infty \\
\stackrel{\infty}{\infty} \\
i n\end{array}$ & 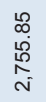 & 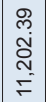 & 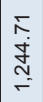 \\
\hline$\frac{\pi}{\frac{\pi}{0}}$ & & $\begin{array}{l}\text { స్ } \\
\text { ડ્స }\end{array}$ & 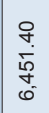 & 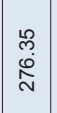 & 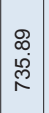 & $\begin{array}{l}\hat{\infty} \\
\text { p. } \\
\text { లn }\end{array}$ & $\begin{array}{l}\stackrel{d}{\infty} \\
\stackrel{m}{\sim}\end{array}$ & $\begin{array}{l}\text { مी } \\
\text { مُ } \\
\stackrel{2}{\leftarrow}\end{array}$ & $\begin{array}{l}\widetilde{0} \\
\infty \\
\varnothing \\
0\end{array}$ & 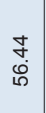 & 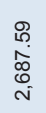 & 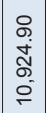 & $\begin{array}{l}\infty \\
\infty \\
\stackrel{\infty}{N} \\
\stackrel{N}{\sim}\end{array}$ \\
\hline $\begin{array}{l}\overrightarrow{0} \\
\text { ம் } \\
.\end{array}$ & & 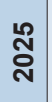 & 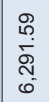 & 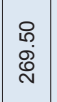 & $\begin{array}{l}\hat{0} \\
\stackrel{i}{i} \\
\hat{N}\end{array}$ & 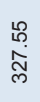 & 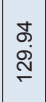 & $\begin{array}{l}8 \\
\stackrel{\leftrightarrow}{\stackrel{2}{\circ}}\end{array}$ & $\begin{array}{l}\text { హ్ } \\
0 \\
0\end{array}$ & $\begin{array}{l}\text { ¿ } \\
\text { 峞 }\end{array}$ & 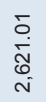 & 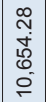 & $\begin{array}{l}\bar{\infty} \\
\infty \\
\infty \\
\check{\sigma}\end{array}$ \\
\hline 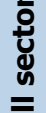 & $\stackrel{0}{\frac{2}{\sigma}}$ & ণ্ণ & 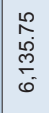 & 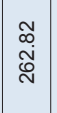 & $\begin{array}{l}\mathscr{8} \\
0 \\
8 \\
8 \\
0\end{array}$ & $\begin{array}{l}\frac{J}{J} \\
\stackrel{j}{m}\end{array}$ & $\begin{array}{l}\stackrel{N}{N} \\
\stackrel{\leftrightarrow}{\sim} \\
\end{array}$ & $\begin{array}{l}\stackrel{N}{N} \\
\stackrel{2}{R}\end{array}$ & 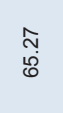 & 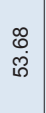 & 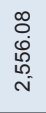 & $\begin{array}{l}\hat{\tilde{m}} \\
\stackrel{8}{0} \\
\tilde{e} \\
0 \\
0\end{array}$ & $\begin{array}{l}\text { g } \\
\text { d } \\
\stackrel{5}{5} \\
-\end{array}$ \\
\hline $\begin{array}{l}\text {. } \\
\text { 응 }\end{array}$ & $\stackrel{0}{\check{2}}$ & స్ণ & $\begin{array}{l}0 \\
0 \\
\infty \\
\infty \\
\infty \\
\infty \\
\infty\end{array}$ & $\begin{array}{l}\bar{m} \\
\stackrel{0}{0} \\
\stackrel{d}{N}\end{array}$ & 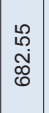 & 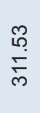 & 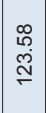 & $\begin{array}{l}\stackrel{g}{q} \\
\stackrel{6}{0} \\
\stackrel{6}{-}\end{array}$ & $\begin{array}{l}\varrho \\
\varnothing \\
\varnothing\end{array}$ & ஸొ & 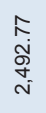 & $\begin{array}{l}\infty \\
\stackrel{\infty}{0} \\
\tilde{m} \\
0 \\
0 \\
0\end{array}$ & 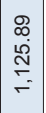 \\
\hline $\begin{array}{l}\text { ம் } \\
\text { '̊̊ }\end{array}$ & & స్ & 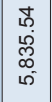 & 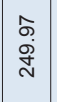 & 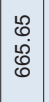 & 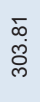 & 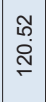 & $\begin{array}{l}\hat{m} \\
\stackrel{\text { }}{\sigma}\end{array}$ & $\begin{array}{l}\text { ọ } \\
\text { ชิ }\end{array}$ & 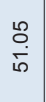 & 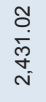 & 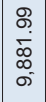 & $\begin{array}{l}8 \\
\infty \\
8 \\
8 \\
-\end{array}$ \\
\hline 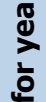 & & స్ণ & $\begin{array}{l}8 \\
8 \\
8 \\
8 \\
\\
i 5\end{array}$ & $\begin{array}{l}\hat{N} \\
\dot{j} \\
d\end{array}$ & 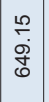 & 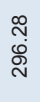 & 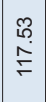 & $\begin{array}{l}\stackrel{\infty}{\infty} \\
\infty \\
\stackrel{\infty}{\leftarrow}\end{array}$ & 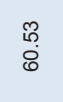 & $\begin{array}{l}\stackrel{9}{\alpha} \\
\stackrel{g}{q}\end{array}$ & $\begin{array}{l}0 \\
\infty \\
0 \\
0 \\
0 \\
\text { iv }\end{array}$ & 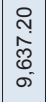 & $\begin{array}{l}8 \\
0 \\
0 \\
0 \\
0 \\
-\end{array}$ \\
\hline$\frac{\frac{0}{\pi}}{\frac{5}{2}}$ & & స્ণ & 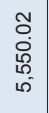 & $\begin{array}{l}\stackrel{\mathfrak{R}}{\mathfrak{N}} \\
\stackrel{\mathfrak{N}}{ }\end{array}$ & 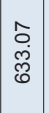 & $\begin{array}{l}\text { के } \\
\infty \\
\infty \\
\stackrel{\infty}{N}\end{array}$ & $\begin{array}{l}\mathbb{O} \\
\stackrel{0}{+} \\
\stackrel{+}{\leftarrow}\end{array}$ & 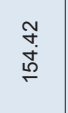 & 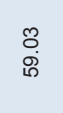 & $\begin{array}{l}0 \\
\infty \\
\infty \\
\infty \\
\dot{\sigma}\end{array}$ & 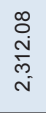 & 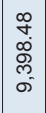 & \begin{tabular}{l}
$\stackrel{\infty}{N}$ \\
\multirow{J}{*}{} \\
$\stackrel{-}{-}$
\end{tabular} \\
\hline 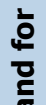 & & $\stackrel{\circ}{\check{N}}$ & 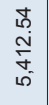 & $\begin{array}{l}\stackrel{\infty}{\infty} \\
\stackrel{\bar{j}}{\sim}\end{array}$ & 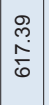 & 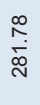 & 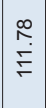 & 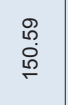 & 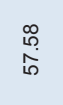 & 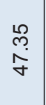 & 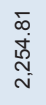 & $\begin{array}{l}\hat{0} \\
\dot{0} \\
\stackrel{0}{0} \\
\sigma\end{array}$ & $\begin{array}{l}\bar{\sigma} \\
\infty \\
\delta \\
\delta \\
-\end{array}$ \\
\hline 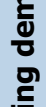 & & $\stackrel{\infty}{\check{N}}$ & 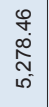 & 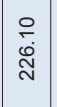 & $\begin{array}{l}0 \\
\stackrel{2}{i} \\
\stackrel{0}{0}\end{array}$ & 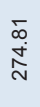 & 立 & $\begin{array}{l}\hat{\infty} \\
\dot{0} \\
\stackrel{\sigma}{\sigma}\end{array}$ & $\frac{L}{\stackrel{6}{\circ}}$ & $\stackrel{\infty}{\frac{\infty}{\dot{g}}}$ & $\begin{array}{l}\qquad 2 \\
\infty \\
\infty \\
\circ \\
\stackrel{i}{i}\end{array}$ & $\begin{array}{l}\tilde{O} \\
\infty \\
\infty \\
\tilde{O} \\
\infty \\
\infty\end{array}$ & $\stackrel{\infty}{\stackrel{\infty}{\delta}}$ \\
\hline 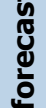 & & స్ำ & 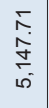 & 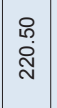 & 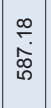 & $\begin{array}{l}\stackrel{8}{0} \\
o \\
\stackrel{0}{0}\end{array}$ & $\begin{array}{l}\bar{p} \\
\stackrel{0}{0} \\
\stackrel{0}{0}\end{array}$ & $\begin{array}{l}\stackrel{\mathscr{N}}{\mathscr{\vartheta}} \\
\stackrel{\vartheta}{\sigma}\end{array}$ & $\begin{array}{l}\stackrel{0}{\circ} \\
\stackrel{5}{\dot{5}}\end{array}$ & 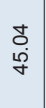 & 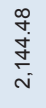 & 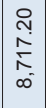 & $\begin{array}{l}\infty \\
\infty \\
\infty \\
\varnothing \\
\varnothing\end{array}$ \\
\hline हू & & $\stackrel{\oplus}{\sim}$ & $\begin{array}{l}\text { ని } \\
\text { ỗ } \\
0 \\
\text { in }\end{array}$ & $\begin{array}{l}\frac{d}{0} \\
\stackrel{\phi}{\sim} \\
i\end{array}$ & 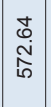 & $\begin{array}{l}\stackrel{0}{\oplus} \\
\stackrel{0}{\circ} \\
\stackrel{N}{N}\end{array}$ & 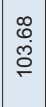 & $\begin{array}{l}\infty \\
\stackrel{\infty}{\circ} \\
\stackrel{\rho}{\longrightarrow}\end{array}$ & 古 & 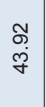 & 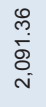 & $\begin{array}{l}\stackrel{\infty}{N} \\
\stackrel{5}{0} \\
\infty \\
\infty \\
\infty\end{array}$ & 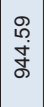 \\
\hline 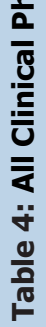 & & 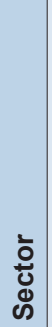 & 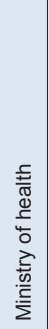 & 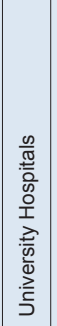 & 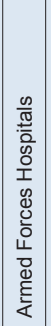 & 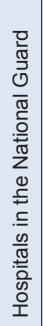 & 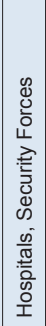 & 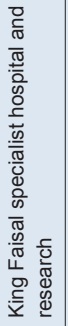 & 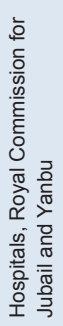 & 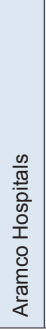 & 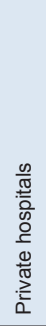 & \begin{tabular}{|l|}
$\bar{\pi}$ \\
$\stackrel{0}{\circ}$
\end{tabular} & 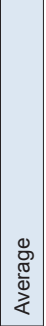 \\
\hline
\end{tabular}

pharmacist works at primary care centers. The detail demand with detail specialties of clinical pharmacist need further investigations in the future.

\section{CONCLUSION}

The projection of clinical pharmacists at $\mathrm{MOH}$ hospitals, primary care centers, and non-governmental hospitals with private hospitals is vital for pharmacy strategic plan and Saudi vision 2030 implementation.

\section{ACKNOWLEDGEMENT}

None.

\section{CONFLICT OF INTEREST}

None.

\section{SOURCE OF SUPPORT}

None.

\section{ABBREVIATIONS USED}

TPNS-Total parenteral nutrition services, KFSH and RC-King Faisal Specialist hospital and research center, KKUH -King Khalid University Hospital, GAPC - General Administration of Pharmaceutical care, $\mathrm{MOH}$ Ministry of Health, ASHP - American society of health system pharmacist.

\section{REFERENCES}

1. Ministry of Health. A Cheivements 2013. 1st Ed. Riyadh, Saudi Arabia: Ministry of Health, Saudi Arabia. 2011:132-5.

2. Alomi YA, Alghamdi SJ, Alattyh RA. Strategic Plan of General Administration of Pharmaceutical Care at Ministry of Health in Saudi Arabia. 2012-2022. J Pharm Pharm Scien. 2015;1(3):1

3. Alomi YA. National Pharmacy Practice Programs at Ministry of Health in Saudi Arabia. JPharm Pharm Scien. 2015;1(2):17-8.

4. Mcleod DC. Contrast in Pharmacy Manpower Planning between the United States and Northen European Countries. Drug Intell Clin Pharm. 1986;20:210-2.

5. HRSA. A study of the supply and demand for pharmacists. Department of Health and Human Services. 2000;100. Available from: www.fip.org/humanresource.

6. Bond CA, Raehl CL, Patry R. Evidence-based core clinical pharmacy services in United States hospitals in 2020: services and staffing. Pharmacotherapy. 2004;24(4):427-40.

7. Bond CA, Raehl CL. Clinical pharmacy services, pharmacy staffing, and adverse drug reactions in United States hospitals. Pharmacotherapy. 2006;26(6):735-47.

8. Bond CA, Raehl CL. Clinical pharmacy services, pharmacy staffing, and hospital mortality rates. Pharmacotherapy. 2007;27(4):481-93.

9. Hawthorne N, Anderson C. The global pharmacy workforce: A systematic review of the literature. Hum Resour Health. 2009;7(1):48.

10. Gal D, Bates I. FIP Global Pharmacy Workforce Report. 2012. Available from: www.fip.org/humanresource

11. Workforce H. Pharmacist Workforce, 2012 — Provincial / Territorial Highlights. 2012.

12. Health Workforce Australia. Australia's Health Workforce Series: Pharmacists in Focus. 2014:1-47.

13. Gaither CA, Schommer JC, Doucette WR, Kreling DH, Mott DA. National Pharmacist Workforce Survey. Workforce. 2015. Available from:http://www. pharmacy.wsu.edu/information/2009.Pharmacist.Workforce.Survey.pdf.

14. Evan Robinson, Natalia Shcherbakova LB. Assessment of Pharmacy Manpower and Services in New England. Journal Pharm Pract. 2016;29(6):549-55.

15. Pedersen CA, Schneider PJ, Scheckelhoff DJ. ASHP national survey of pharmacy practice in hospital settings: Dispensing and administration - 2014. Am J Heal Pharm. 2015;72(13):1119-37.

16. Knapp DA. Professionally determined need for pharmacy services in 2020. Am J Pharm Ed. 2002;66(4):421-9.

17. Health Statistical Year Book. Saudi Ministry of Health; 2006. Available from: http:// www.moh.gov.sa/en/Ministry/Statistics/book/Pages/default.aspx.

18. Health Statistical Year Book. Saudi Ministry of Health; 2007. Available from: http:// 
www.moh.gov.sa/en/Ministry/Statistics/book/Pages/default.aspx.

19. Health Statistical Year Book. Saudi Ministry of Health; 2008. Available from: http:// www.moh.gov.sa/en/Ministry/Statistics/book/Pages/default.aspx.

20. Health Statistical Year Book. Saudi Ministry of Health; 2009. Available from: http:// www.moh.gov.sa/en/Ministry/Statistics/book/Pages/default.aspx.

21. Health Statistical Year Book. Saudi Ministry of Health; 2010. Available from: http:// www.moh.gov.sa/en/Ministry/Statistics/book/Pages/default.aspx.

22. Health Statistical Year Book. Saudi Ministry of Health; 2011. Available from: http:// www.moh.gov.sa/en/Ministry/Statistics/book/Pages/default.aspx.

23. Health Statistical Year Book. Saudi Ministry of Health; 2012. Available from: http:// www.moh.gov.sa/en/Ministry/Statistics/book/Pages/default.aspx.

24. Health Statistical Year Book. Saudi Ministry of Health; 2013. Available from: http:// www.moh.gov.sa/en/Ministry/Statistics/book/Pages/default.aspx.

25. Health Statistical Year Book. Saudi Ministry of Health; 2014. Available from: http:// www.moh.gov.sa/en/Ministry/Statistics/book/Pages/default.aspx.

26. Health Statistical Year Book. Saudi Ministry of Health; 2015. Available from: http:// www.moh.gov.sa/en/Ministry/Statistics/book/Pages/default.aspx.

27. Health Statistical Year Book. Saudi Ministry of Health; 2016. Available from: http:// www.moh.gov.sa/en/Ministry/Statistics/book/Pages/default.aspx.

28. American Society of Hospital Pharmacists. ASHP Statement on Pharmaceutical Care. Am J Hosp Pharm. 1993;50:1720-3.
29. ASHP Guidelines on a Standardized Method for Pharmaceutical Care. Am Soc Heal Pharm. 1996;53(14):1713-6.

30. Medication Management (MM). In: National Hospital Standards. 2nd Ed. Saudi Central Board for Accreditation of Healthcare Institutions; 2015;194-211.

31. The Joint Commission. Comprehensive Accreditation Manuals. Joint Commission Resources. Available from: http://www.jcrinc.com/store/publications/manuals/.

32. Alomi Y, Mudaiheem HA. National Drug Information Center Services through Ministry of Health Hotline Calling Center (937) in Saudi Arabia. Adv Pharmacoepidemiol Drug Saf. 2016;5(1).

33. Alomi YA. National Medication Safety Program at Ministry of Health in Saudi Arabia. J Pharmacovigi. 2015;3(5):1-2.

34. Alomi YA. National pharmacy anticoagulation program at Ministry of Health in Saudi Arabia. BAOJ Pharm Sci. 2017;3(3):3-7.

35. Alomi YA. National Pharmacy Pain Management Program at Ministry of Health in Saudi Arabia. J Pharmacol Clin Res. 2017;3(2).

36. Alomi YA, Ahmed AY, Pharm B, Clin PM. A new Guidelines on Hospital Pharmacy Manpower in Saudi Arabia. J Pharm Pract Community Med. 2016;2(2).

37. Alomi YA. Primary Care Center Pharmacy Manpower New Guidelines in Saudi Arabia. J Pharmacol Clin Res. 2016;1(1).

Cite this article as: Alomi YA, Alghamdi SJ, Alattyh RA. Forecasting the Demand of Clinical Pharmacist Workforce in Future Fifteen Years (2016-2030) at all Healthcare institutions in Saudi Arabia. J Pharm Pract Community Med. 2018;4(1s):S92-S6. 